Figure 1: Time until First transition to Good and No EULAR Response (DAS28-ESR)



References:

[1] Taylor et el. 2015 ACR Meeting. Abstract 2L.

[2] Dougados M, et al. Ann Rheum Dis. 29 Sep 2016.

[3] Smolen et al. Ann Rheum Dis. 31 Oct 2016.

[4] Fleischmann R et al. Arthritis Rheumatol. 09 Oct 2016.

[5] Kremer et al. 2015 ACR Meeting. Abstract 1050.

[6] Gestel et al. Arthritis Rheum 1996.

[7] Lin G et al. SAS Global Forum 2012

Acknowledgements: Inmaculada de la Torre MD, PhD, Senior Medical Advisor, contributed to this abstract.

Disclosure of Interest: T. K. Kvien Consultant for: AbbVie, Biogen, BMS, Boehringer Ingelheim, Celltrion, Eli Lilly, Epirus, Janssen, Merck-Serono, MSD, Mundipharma, Novartis, Oktal, Orion Pharma, Hospira/Pfizer, Roche, Sandoz, and UCB, Speakers bureau: AbbVie, Biogen, BMS, Boehringer Ingelheim, Celltrion, Eli Lilly, Epirus, Janssen, Merck-Serono, MSD, Mundipharma, Novartis, Oktal, Orion Pharma, Hospira/Pfizer, Roche, Sandoz, and UCB, P. van Riel Consultant for: Eli Lilly and Company, A. Rubbert-Roth Consultant for: Eli Lilly and Company, R. Blanco Consultant for: Eli Lilly and Company, S. S. Liu-Leage Shareholder of: Eli Lilly and Company, Employee of: Eli Lilly and Company, E. Larsson Shareholder of: Eli Lilly and Company, Employee of: Eli Lilly and Company, $\mathrm{H}$. Lund Shareholder of: Eli Lilly and Company, Employee of: Eli Lilly and Company, P. López-Romero Shareholder of: Eli Lilly and Company, Employee of: Eli Lilly and Company, L. Zaremba-Pechmann Shareholder of: Eli Lilly and Company, Employee of: Eli Lilly and Company, P. Emery Consultant for: Pfizer, MSD, Abbvie, BMS, UCB, Roche, Novartis, Samsung, Sandoz, Eli Lilly and Company DOI: 10.1136/annrheumdis-2017-eular.2217

\section{SAT0071 RHEUMATOID ARTHRITIS (RA) REGISTRY IN AKITA PREFECTURE, WHERE AGING IS THE MOST ADVANCED IN JAPAN}

T. Aizawa $^{1}$, T. Kashiwagura ${ }^{2}$, N. Mlyakoshi ${ }^{3}$, Y. Shimada ${ }^{3} .{ }^{1}$ Dept. of Orthopedic Surgery, Kitaakita Municipal Hospital, Kitaakita City; ${ }^{2}$ Akita City Hospita; ${ }^{3}$ Dept. of Orthopedic Surgery, Akita University Graduate School of Medicine, Akita City, Japan

Background: The rate of aging (percentage of population aged 65 years and over) in Akita Prefecture is $33.8 \%$ (26.6\% for the whole of Japan), the highest throughout Japan. The Akita Orthopaedic Group on Rheumatoid Arthritis (AORA) was established in 2010. Since then, patients have been enrolled every year to prepare the registry.

Objectives: To compare patient characteristics as well as clinical effectiveness between the treatments with and without use of methotrexate (MTX) and a biological $(\mathrm{BIO})$ using the data of the AORA registry.

Methods: The subjects were 2,016 patients enrolled in the Akita registry in 2015. The subjects included 403 men and 1,613 women. According to the use of MTX and $\mathrm{BIO}, 2,016$ patients were divided into the group treated with no use of MTX or $\mathrm{BIO}$ (group A), that treated with BIO, but no use of MTX (group B), that treated with MTX, but no use of BIO (group C), and that treated with MTX and BIO (group D).
Results: The subjects were grouped into group A ( $n=673), B(n=153), C \quad(n=805)$, and D ( $n=385)$. MTX was used in $59.0 \%$ and BIO was used in $26.7 \%$ of all patients. The mean ages were 69.6 years (group A), 65.7 years (group B), 65.6 years (group C), and 62.6 years (group D). The aging rates were $67.9 \%$ (group A), $55.6 \%$ (group B), $56.8 \%$ (group C), and $48.3 \%$ (group D), which shows that aging was more advanced in group $A$.

The rates of patients with a complication of hypertension, diabetes, respiratory disease, cerebrovascular disease, heart disease or malignant tumour were $52.0 \%$ (group A), 54.2\% (group B), 45.5\% (group C), and 40.8\% (group D). The incidence of complication was the lowest in group $\mathrm{D}$.

The rates of patients who received one or more of conventional synthetic diseasemodifying antirheumatic drugs (cs DMARDs) other than MTX were $79.0 \%$ (group A), $42.5 \%$ (group B), 39.9\% (group C), and 19.2\% (group D). Although bucillamine and salazosulfapyridine were frequently used in any group, concomitant use of tacrolimus was remarkable in group $\mathrm{A}$ and $\mathrm{C}$, while that of iguratimod was remarkable in groups $C$ and $D$. The rate of use of a prednisolone (PSL), was significantly higher in group $\mathrm{B}$. The dose of PSL was significantly higher in group $\mathrm{A}$. In regard to $\mathrm{BIO}$, three drugs of etanercept, tocilizumab, and abatacept accounted for $90 \%$ in group B. In group D, etanercept and tocilizumab were also frequently used, followed by infliximab, adalimumab, golimumab and abatacept. In DAS28ESR, the rate of combined low disease activity and remission was significantly higher in group $\mathrm{D}$. The mean values of $\mathrm{C}$-reactive protein (CRP) (mg/dL) were 0.61 (group A), 0.52 (group B), 0.47 (group C), and 0.35 (group D), which shows that the mean value was significantly higher in group $A$ than group D. The mean values of matrix metalloproteinase 3 (MMP3) $(\mathrm{ng} / \mathrm{dL})$ were 119.0 (group A), 130.6 (group B), 100.7 (group C), and 88.9 (group D), which shows that the mean value was significantly higher in group $A$ and $B$ than group $C$ and $D$. Conclusions: Using the AORA registry, we compared patient characteristics as well as clinical effectiveness between the treatments with and without use of MTX and BIO. Since in group A, neither MTX nor BIO could be used in most patients, one had to practically rely on PSL. The study suggests that remission needs to be achieved prior to increase in complication due to aging.

References:

[1] Population census in Japan, 2015.

Disclosure of Interest: None declared

DOI: 10.1136/annrheumdis-2017-eular.2560

\section{SAT0072 DOSE REDUCTION OF BARICITINIB IN PATIENTS WITH RHEUMATOID ARTHRITIS ACHIEVING SUSTAINED DISEASE CONTROL: RESULTS OF A PROSPECTIVE STUDY}

T. Takeuchi ${ }^{1}$, M. Genovese ${ }^{2}$, B. Haraoui ${ }^{3}$, L. Xie ${ }^{4}$, R. Klar ${ }^{5}$, A. Luisa Pinto Correia $^{4}$, T. Rooney ${ }^{4}$, S. Otawa ${ }^{4}$, J.S. Smolen $6 .{ }^{1}$ Keio University, Tokyo, Japan; ${ }^{2}$ Stanford University Medical Center, Palo Alto, United States; ${ }^{3}$ Centre Hospitalier de I'Université de Montréal, Montreal, Canada; ${ }^{4}$ Eli Lilly and Company, Indianapolis; ${ }^{5}$ Quintiles IMS Holdings, Inc, Durham, United States; ${ }^{6}$ Medical University of Vienna, Vienna, Austria

Background: In patients (pts) with active rheumatoid arthritis (RA) and inadequate response (IR) to DMARDs, ph3 studies demonstrated efficacy of baricitinib (bari) (2mg and $4 \mathrm{mg}$ ). Larger, more rapid treatment effects were observed for bari $4 \mathrm{mg}$. Objectives: To investigate the effects of bari dose step-down in pts who achieved sustained disease control with bari $4 \mathrm{mg}$.

Methods: Pts with RA who completed a bari ph3 study could enter a long-term extension (LTE) study. In the LTE, pts who received bari $4 \mathrm{mg}$ for $\geq 15$ months and who achieved sustained low disease activity ([LDA]-CDAI score $\leq 10$ ) or remission $(\mathrm{CDAl} \leq 2.8)$ at 2 consecutive visits $\geq 3$ months apart were re-randomised in a blinded manner to continue bari $4 \mathrm{mg}$ or step down to $2 \mathrm{mg}$. Patients could rescue (to bari $4 \mathrm{mg}$ ) if CDAI >10. Efficacy and safety were assessed through 48 weeks (wks) following re-randomisation.

Results: Among pts who achieved sustained disease control with bari $4 \mathrm{mg}$, dose reduction to $2 \mathrm{mg}$ resulted in significant increases in disease activity at 12,24 , and $48 \mathrm{wks}$; however, the majority of pts in both groups maintained the state of LDA

Abstract SAT0072 - Table 1

\begin{tabular}{|c|c|c|c|c|c|c|}
\hline & \multicolumn{6}{|c|}{ Pts originating from RA-BEAM, RA-BUILD, RA-BEACON Combined ${ }^{\dagger}$} \\
\hline & \multicolumn{2}{|c|}{ Week 12} & \multicolumn{2}{|c|}{ Week 24} & \multicolumn{2}{|c|}{ Week 48} \\
\hline & $\begin{array}{c}\text { Continued bari } 4 \mathrm{mg} \\
\mathrm{N}=396\end{array}$ & $\begin{array}{l}\text { Stepped down to bari } 2 \mathrm{mg} \\
\mathrm{N}=394\end{array}$ & $\begin{array}{c}\text { Continued bari } 4 \mathrm{mg} \\
\mathrm{N}=353\end{array}$ & $\begin{array}{l}\text { Stepped down to bari } 2 \mathrm{mg} \\
\mathrm{N}=358\end{array}$ & $\begin{array}{l}\text { Continued bari } 4 \mathrm{mg} \\
\qquad \mathrm{N}=245\end{array}$ & $\begin{array}{l}\text { Stepped down to bari } 2 \mathrm{mg} \\
\mathrm{N}=245\end{array}$ \\
\hline Efficacy measure & \multicolumn{6}{|c|}{ NRI after rescue or for missing data } \\
\hline CDAI LDA $\leq 10$ & $359 / 396(90.7)$ & $326 / 393(83.0)^{\star \star}$ & $309 / 353(87.5)$ & $269 / 357(75.4)^{\star \star \star}$ & 198/245 (80.8) & $167 / 245(68.2)^{\star \star}$ \\
\hline \multirow[t]{2}{*}{ CDAl remission $\leq 2.8$} & $158 / 396(39.9)$ & $143 / 393(36.4)$ & $149 / 353(42.2)$ & $127 / 357(35.6)$ & $99 / 245(40.4)$ & $82 / 245(33.5)$ \\
\hline & \multicolumn{6}{|c|}{ NRI only for missing data (observed data used after rescue) } \\
\hline CDAI LDA $\leq 10$ & $359 / 396(90.7)$ & $326 / 393(83.0)^{\star \star}$ & $314 / 353(89.0)$ & $289 / 357(81.0)^{\star \star}$ & $212 / 245(86.5)$ & $196 / 245(80.0)$ \\
\hline CDAl remission $\leq 2.8$ & 158/396 (39.9) & $143 / 393(36.4)$ & $150 / 353(42.5)$ & $133 / 357(37.3)$ & $103 / 245(42.0)$ & $90 / 245(36.7)$ \\
\hline Safety measure & & & & is $0-48$ & & \\
\hline $\mathrm{n}$ [EAIR/100 PYE] & \multicolumn{3}{|c|}{ Continued bari $4 \mathrm{mg} \mathrm{N}=396$} & \multicolumn{3}{|c|}{ Stepped down to bari $2 \mathrm{mg} \mathrm{N}=394$} \\
\hline SDEAE & \multicolumn{3}{|c|}{$225[70.5]$} & \multicolumn{3}{|c|}{$196[65.4]$} \\
\hline Infection & \multicolumn{3}{|c|}{99 [31.0] } & \multicolumn{3}{|c|}{70 [23.3] } \\
\hline SAE & \multirow{2}{*}{\multicolumn{3}{|c|}{$23[7.2]$}} & \multicolumn{3}{|c|}{$23[7.7]$} \\
\hline Serious infection & & & & \multicolumn{3}{|c|}{$4[1.3]$} \\
\hline $\mathrm{AE} \rightarrow$ discontinuation & \multicolumn{2}{|r|}{9 [2.8] } & & \multicolumn{3}{|c|}{$11[3.6]$} \\
\hline
\end{tabular}

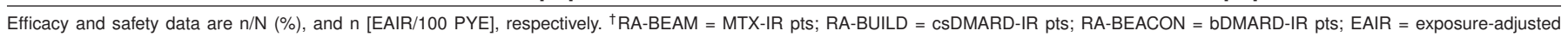
incidence rate; $\mathrm{NRI}=$ nonresponder imputation; $\mathrm{PYE}=$ patient-years of exposure; SDEAE = step-down emergent adverse event. ${ }^{\star \star} \mathrm{p} \leq 0.01,{ }^{{ }^{* *} \mathrm{p}} \leq 0.001 \mathrm{vs}$. continued bari $4 \mathrm{mg}$. 